\title{
Vietnam's Future Water Usage Model: A Controlled Living Experiment
}

\author{
Kanako Toyosada ${ }^{*}$, Takayuki Otani1,2,3, Yasutoshi Shimizu4, Hiroshi Takata5, \\ Kazuhiko Sakamoto', Saburo Murakawa ${ }^{7}$, Shunsuke Managi ${ }^{3}$ \\ ${ }^{1}$ Department of Environmental Science, Fukuoka Women's University, Fukuoka, Japan \\ ${ }^{2}$ ESG Promotion Department, TOTO Ltd., Fukuoka, Japan \\ ${ }^{3}$ Urban Institute \& Departments of Urban and Environmental Engineering, Kyushu University, Fukuoka, Japan \\ ${ }^{4}$ Water and Lifestyle Research Laboratory, Fukuoka, Japan \\ ${ }^{5}$ Graduate School of Education, Hiroshima University, Hiroshima, Japan \\ ${ }^{6}$ Department of Architecture, Okayama University of Science, Okayama, Japan \\ ${ }^{7}$ Hiroshima University, Hiroshima, Japan \\ Email: *kanako.toyosada@fwu.ac.jp
}

How to cite this paper: Toyosada, K., Otani, T., Shimizu, Y., Takata, H., Sakamoto, K., Murakawa, S. and Managi, S. (2018) Vietnam's Future Water Usage Model: A Controlled Living Experiment. Journal of Water Resource and Protection, 10, 204-214.

https://doi.org/10.4236/jwarp.2018.102012

Received: January 26, 2018

Accepted: February 25, 2018

Published: February 28, 2018

Copyright $\odot 2018$ by authors and Scientific Research Publishing Inc. This work is licensed under the Creative Commons Attribution International License (CC BY 4.0).

http://creativecommons.org/licenses/by/4.0/

\begin{abstract}
The purpose of this study was to explore the water usage profile of future Vietnamese households by carrying out a controlled living experiment with $\mathrm{Vi}$ etnamese high-income households. By studying showering time, flow rate and toilet-use frequency of these households, the study revealed the water usage believed to be representative of future households in light of continued urbanization. This study also determined that the average time of showering was 9.7 minutes per person per day with an average flow rate of $12 \mathrm{~L} /$ minute for the existing shower head and $6.6 \mathrm{~L} /$ minute for the water-saving shower head. Toilet usage frequency was 5.25 times per person per day, and there was no difference with the results for an average (middle-income) household.
\end{abstract}

\section{Keywords}

Water-Saving Equipment, Water Usage, Controlled Living Experiment, Vietnamese Household

\section{Introduction}

As a measure against climate change, the Japanese government is promoting the bilateral credit system (Joint Crediting Mechanism: JCM) in order to introduce Japanese advanced low carbon technologies to developing countries and using the quantified reduction in greenhouse gases to reach Japan's reduction target. 
The authors focus on the cobenefit of climate change measures and conservation of water resources, and are progressing feasibility studies in the JCM's aim of promoting water-saving products, such as water-saving showers and toilets [1].

This study found that while large-scale buildings in Vietnam such as hotels maintain sufficient water-supply pressure (henceforth, water pressure), in typical houses insufficient water pressure has created dissatisfaction among users with shower flow rate [1]. The JCM sets a reference scenario (greenhouse gas emission amount if measures are not taken) and this system recognizes the difference in greenhouse gas emissions after project implementation as the reduction amount, however, in the areas with progressing urbanization and infrastructure development, the emissions amount after infrastructure development will become the reference scenario. In the case of showers for bathing, the flow rate after infrastructure development has resolved water pressure deficit will become the reference scenario, however, no information has been reported on existing water usage in Vietnamese households that have consistently sufficient water pressure [2]-[10].

It is expected that the current lifestyle of high income groupspeople receiving more than 1500 US dollars per month in incomewill spread as urbanization continues. Therefore, this study aimed to predict the water usage profile of Vietnam's future households, based on the expectation that urbanization will progress, by focusing on high-income households (income of more than 1500 US dollars per month) that had high water pressure. Hence, this study revealed the profile of showering time, flow rate, and water usage of future Vietnamese households by carrying out a controlled living experiment focused on high income groups in Vietnam living in buildings with high water pressure.

\section{Experiment Method}

In order to set the reference scenario of water usage in Vietnamese households, 9 high-income households (35 Vietnamese people) who lived in houses with consistent water pressure, stayed in test rooms and carried out life as usual. For the test rooms, 3 rooms were used from the high-end Hanoi City serviced apartments. The experiment outline is shown in Table 1 and the experiment room outline is shown in Figure 1.

In previous studies [11] [12], hot and cold water usage has been analysed by installing a flowmeter capable of measuring the flow rate every 2 seconds. The same type of flowmeter and method of analysis was used in this study.

Vietnam extends $1650 \mathrm{~km}$ north to south and $600 \mathrm{~km}$ east to west. Due to its unique terrain, the northern part has a subtropical climate with four seasons, ranging from cold winter to hot summer, while the central part has a warm climate all year round. The southern part is divided into a dry season and a rainy season, with a tropical monsoon climate. This experiment was conducted in Hanoi city located in the northern part of Vietnam. The experiment was carried 
Table 1. Living experiment outline.

\begin{tabular}{|c|c|}
\hline Test period & 1-4 December 2014 \\
\hline Participants & $\begin{array}{l}9 \text { high income households ( } 35 \text { people) living in Hanoi City with } \\
\text { consistent water-supply pressure }\end{array}$ \\
\hline Test site & 3 rooms in a 5 -star serviced apartment in Hanoi City \\
\hline & $\begin{array}{l}\text { 1) Install in each room's machine room a flow meter (water supply sensor, hot } \\
\text { water supply sensor), temperature sensor (thermocouple). } \\
\text { 2) Install a water-saving shower (project device) in each room's bathroom, and } \\
\text { install a flow meter between the faucet and shower hose (cumulative flow display). } \\
\text { 3) Measure the optimum flow rate of the existing shower using a representative of } \\
\text { each household. }\end{array}$ \\
\hline $\begin{array}{c}\text { Experiment } \\
\text { method }\end{array}$ & $\begin{array}{l}\text { 4) Each household in turn stays in one of the rooms for half a day and carries out } \\
\text { usual life from dinner to the following morning's breakfast. While the participants } \\
\text { are staying, each person writes down on a set form the times of using the toilet, } \\
\text { shower, faucets, washing machine, and dishwasher. } \\
\text { 5) When participants use the shower they write the flow amount both before and } \\
\text { after showering shown on the flow meter (2) on a designated form for showering. } \\
\text { 6) Comparing the value on the flowmeter with the values written on the forms, } \\
\text { deduce the amount of water used by each appliance. }\end{array}$ \\
\hline Study items & $\begin{array}{l}\cdot \text { Hot and cold water usage and amount profile of } 1 \text { household per day } \\
\cdot \text { Toilet } \cdot \text { Shower } \cdot \text { Faucets } \cdot \text { Washingmachine } \cdot \text { Dishwasher water amount } \\
\text { consumed and time }\end{array}$ \\
\hline
\end{tabular}

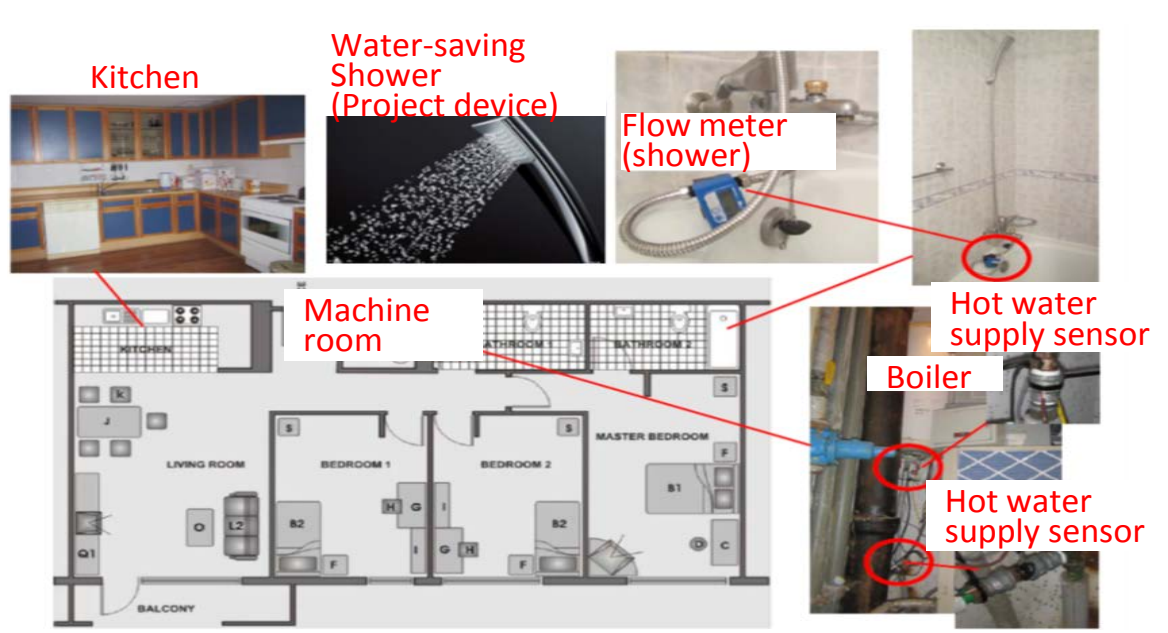

Figure 1. Test room overview.

out in December in winter.

\subsection{Participant Information}

The background of participants is shown in Figure 2. The 9 households (35 people) were from Hanoi City with high incomes of at least 1500 - 2000 $\mathrm{USD} / \mathrm{month}$, and the highest income household was 100,000 USD/month. In terms of gender, there were comparable numbers of men and women. The majority of households were a family of four of a couple and children, and two households were a couple and relatives. All the households were dual income, and no one was a fulltime homemaker. About 30\% were in their 30s, the largest 

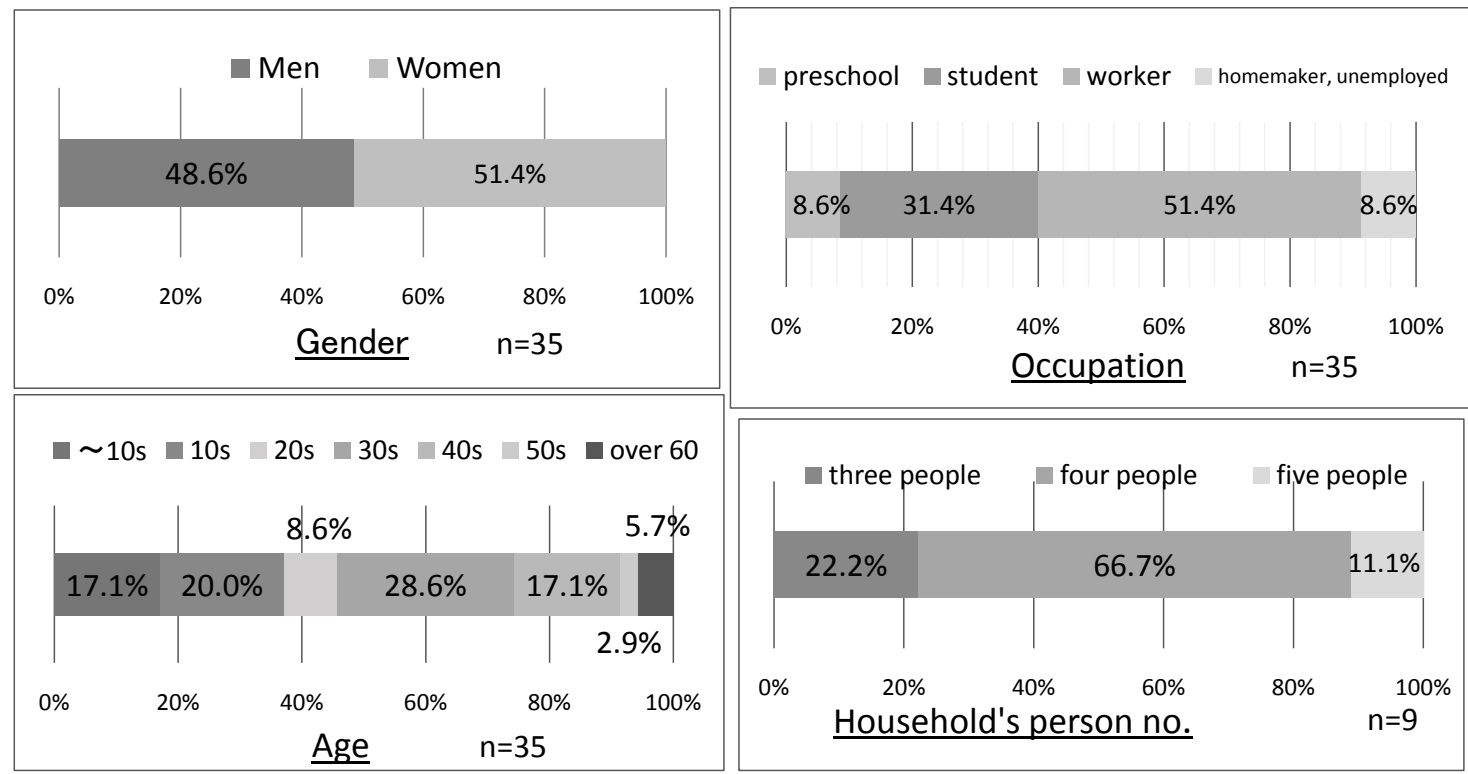

Figure 2. Participant information.

group, and the ages were distributed from 10 to over 60. In Vietnam, it is common to retire at 60 , and all those over 60 were unemployed.

\subsection{Hot and Cold Water Usage Profile}

The hot and cold water usage amount for each household is shown in Table 2. In the experiment, the commencement of the room stay was about 18:00 and leaving was mostly the following morning around 08:00. Although the stays were short at up to 13 hours, each person used per day $100-150 \mathrm{~L}$ of water and the average was $117.8 \mathrm{~L}$. The shower used in this experiment was a water-saving shower with a $35 \%$ water-saving effect, and as the majority of households did not use the washing machine during their stay, it was assumed that the hot and cold water amount used by the households at home would be much greater than the value shown in Table 2. The reason for B-3 having a small amount of $60.5 \mathrm{~L}$ is because their stay was particularly short and breakfast preparation and laundry was not carried out. Also, C-1 is excluded from analysis as there was a data deficiency.

Excluding B-3, B-2 had the lowest level of water usage per person, and C-2 had the highest level: their hot and cold water usage profiles are shown in Figure 3 and Figure 4, respectively. In B-2, at 23:00 the family bathed consecutively, however, in C-2, water was used continuously. According to the action record, in C-2, the dishwasher and washing machine was used, so it is likely that this is why water was continuously used. On the other hand, B-2 did not use either appliances.

The average hot and cold water usage profile of the 9 households is shown in Figure 5. It was found that there were peaks in use around 18:00 when entering the room, before sleeping around 23:00 and after waking around 06:00. 
Table 2. Each household's hot and cold water usage amount participant information.

\begin{tabular}{ccccc}
\hline Family & Stay & $\begin{array}{c}\text { No. of people } \\
\text { staying }\end{array}$ & Per day & Per person per day \\
\hline No. & date & & $\begin{array}{c}\text { Amount of hot and } \\
\text { cold water used }\end{array}$ & $\begin{array}{c}\text { Amount of hot and } \\
\text { cold water used }\end{array}$ \\
\cline { 3 - 5 } & & 4 & [L/day $]$ & {$[\mathrm{L} /$ (person.day) $]$} \\
\hline A-1 & $12 / 1$ & 3 & 475.2 & 118.8 \\
A-2 & $12 / 2$ & 5 & 378.6 & 126.2 \\
A-3 & $12 / 3$ & 4 & 673.2 & 134.6 \\
B-1 & $12 / 1$ & 4 & 472.3 & 118.1 \\
B-2 & $12 / 2$ & 4 & 399.9 & 100.0 \\
B-3 & $12 / 3$ & 4 & 241.9 & 60.5 \\
C-2 & $12 / 2$ & 4 & 622.6 & 155.6 \\
C-3 & $12 / 3$ & 536.3 & 134.1 \\
\hline
\end{tabular}

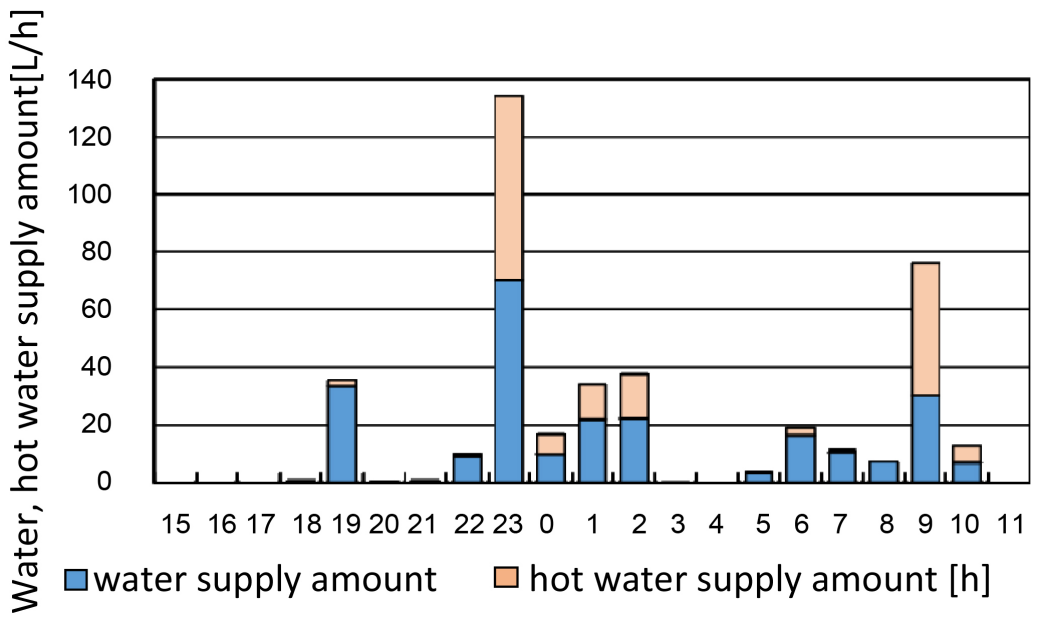

Figure 3. Hot and cold water usage profile (B-2).

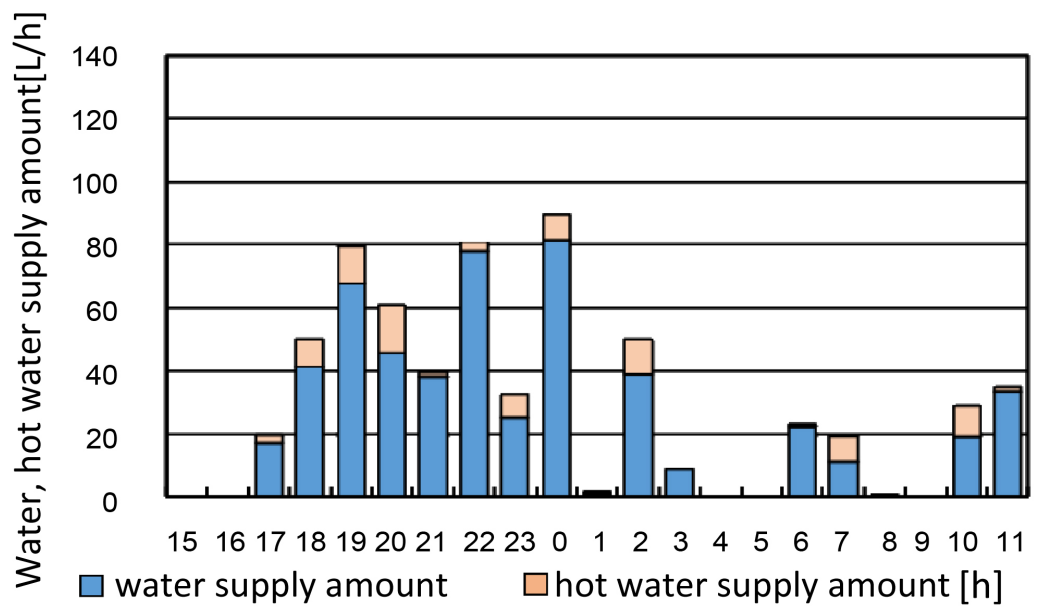

Figure 4. Hot and cold water usage profile (C-2). 


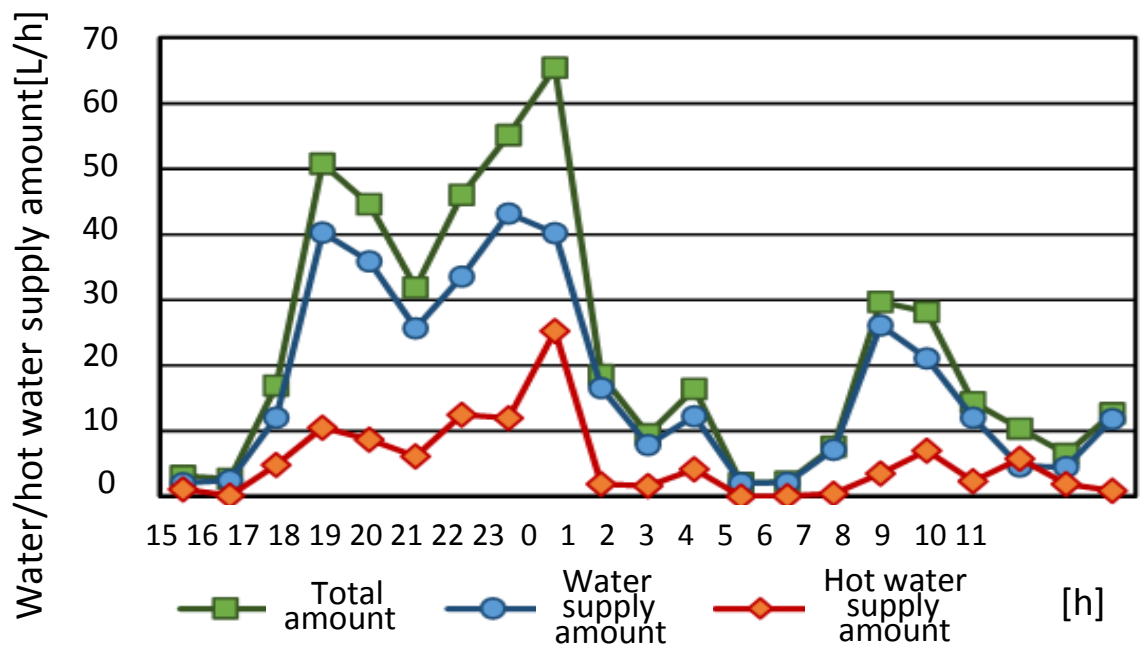

Figure 5. Hot and cold water usage profile (total average).

\subsection{Bathroom Shower's Flowrate Used, Time, Hot and Cold Water Amount}

A representative of each household (total 9 people) used the existing shower in the serviced apartment and the flow rate used when showering normally at home was measured. A rate of $10-13.5 \mathrm{~L} / \mathrm{min}$ was recorded. The average was 12 $\mathrm{L} / \mathrm{min}$ and it was found that they were showering at a stronger flow rate than the assumed optimum flow rate of $10 \mathrm{~L} / \mathrm{min}$ of the existing shower.

The distribution of shower flow rate, after changing to a water-saving shower (optimum flow rate $6.5 \mathrm{~L} / \mathrm{min}$, water-saving effect 35\%), is shown in Figure 6. The average value, and median value were both $6.6 \mathrm{~L} / \mathrm{min}$, the same level as optimum flow rate. The water-saving effect in this experiment $(12 \rightarrow 6.6 \mathrm{~L} / \mathrm{min})$ was $45 \%$, however, after interviewing the representatives of each household, all stated "I did not realize I was saving water. I was able to wash plentifully".

We heard that the project device (water-saving shower) provided both water-saving and comfort.

The frequency of showering in one day is shown in Figure 7. As about 50\% had numerous showers in one day, each showering's flow rate and time was analyzed and is shown in Figure 8. There was no correlation found between shower frequency and flow rate.

Regarding the showering time, the higher the frequency, the longer the showering time, however, for the people who had numerous showers, with each shower the time became shorter. Therefore, it was decided that it was valid to set in the shower use model "showering time per day (total value)", rather than "frequency of showering per day $\times$ time per shower".

The showering time per person per day is shown in Figure 9. Many people showered for 8 - 9 minutes, and the average value was 9.7 minutes.

Figure 10 shows the distribution of hot and cold water used showering. Most were $30 \mathrm{~L}$ but there was wide distribution and the average value was $45.6 \mathrm{~L}$. and the median value was $39.2 \mathrm{~L}$. 


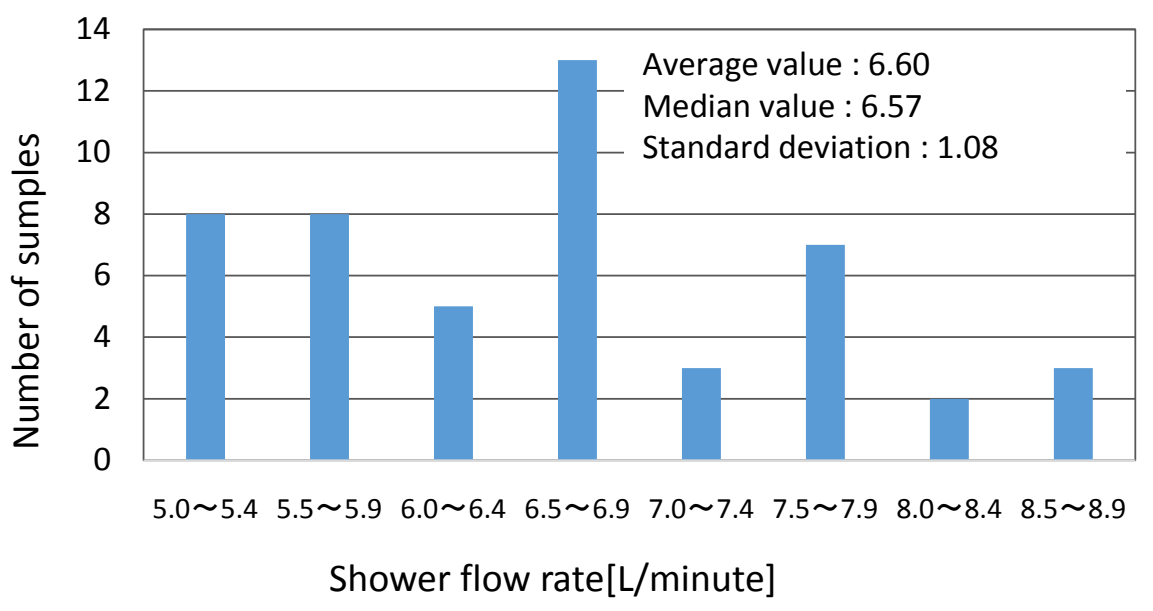

Figure 6. Shower flow rate distribution.

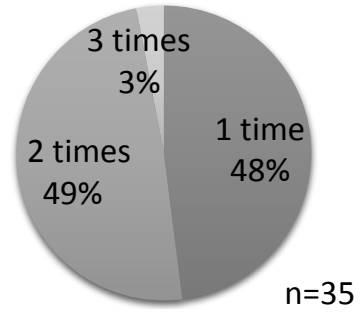

Figure 7. Showering frequency per day.

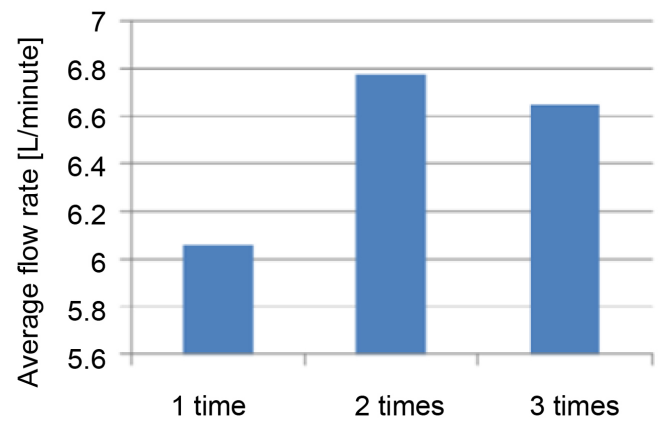

Frequency of showering per day [times/day]

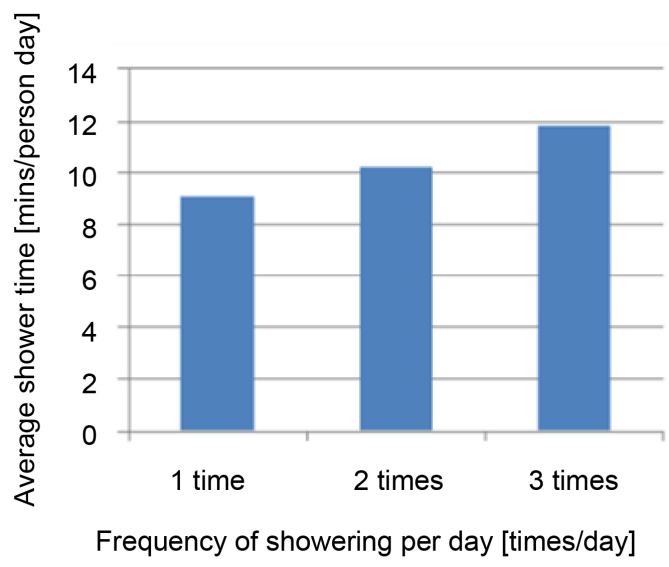

Figure 8. Flow rate, time for each time showering. 


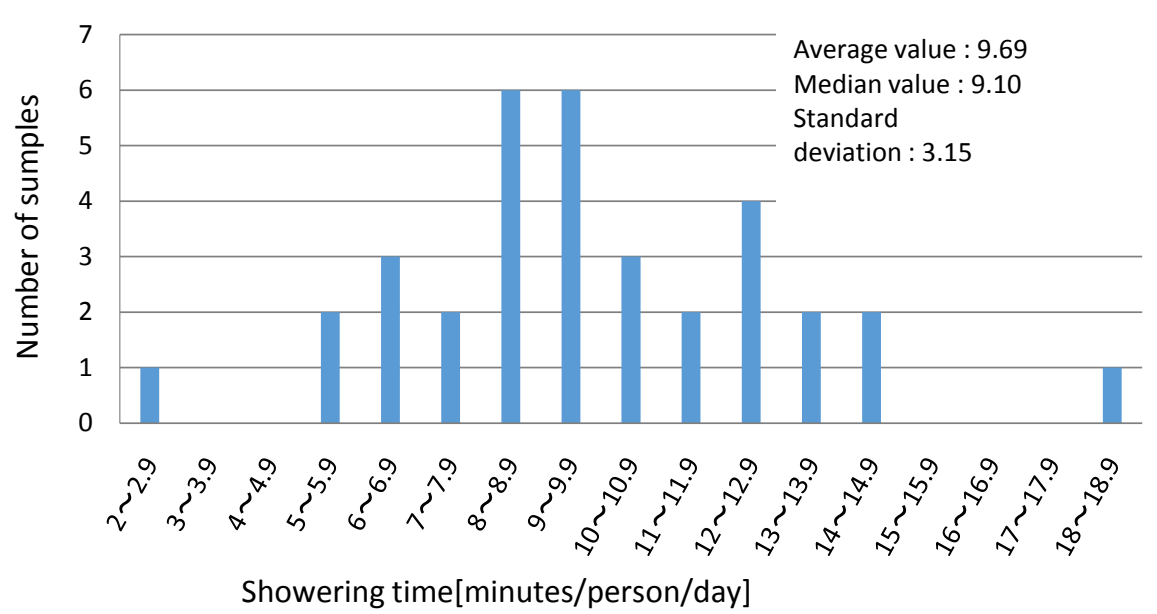

Figure 9. Showering time distribution per person per day.

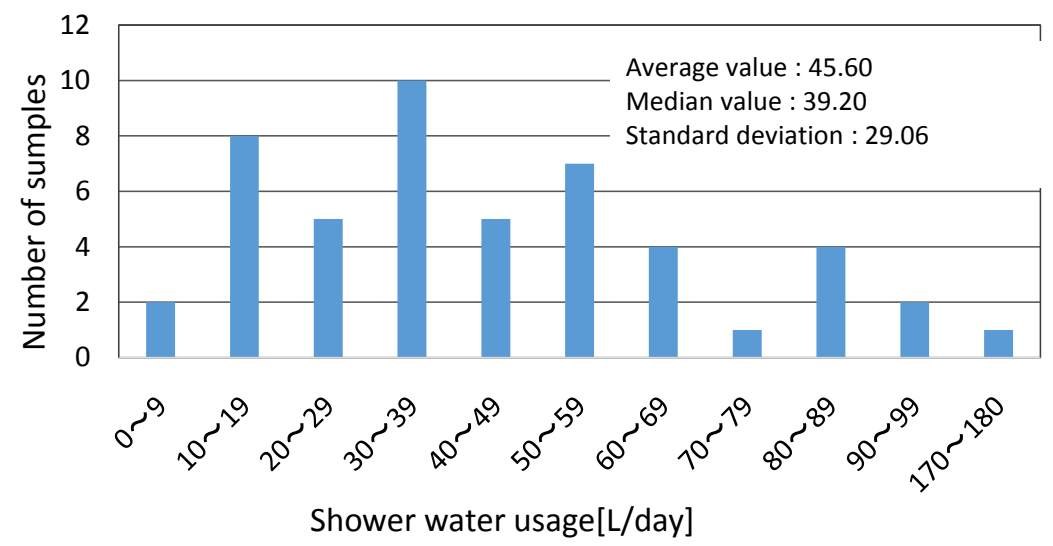

Figure 10. Distribution of shower's water use per day.

\subsection{Toilet Usage Frequency}

Each household's toilet usage frequency (in this report, this refers to toilet flush frequency) is shown in Table 3. As the time of entering and leaving the room differs for each participant, the toilet usage frequency was also widely distributed and the average was 4.5 times (person/day). Regarding toilet usage frequency and participant's background, one type was quantified and a correlation analysis was undertaken, which showed a loose correlation of 0.4 related to occupation (Table 4). Similar to the previous study that focused on Japanese people [11], because of a high correlation between occupation and time spent at home, it is likely that there is a high correlation between occupation and household toilet use frequency. For example, workers use the home toilet less because their time spent at home is short, and the unemployed or homemakers have a longer time spent at home, and so their home toilet use is more frequent. Table 5 shows the toilet usage frequency according to occupation. For the unemployed, their normal period of time spent at home is considered to be longer than the time they were present during the experiment, and thus time spent at home was numerically corrected to 24 hours. 
Table 3. Each household's toilet usage frequency per day.

\begin{tabular}{ccccc}
\hline Family no. & Stay date & Staying & \multicolumn{2}{c}{ Toilet usage frequency } \\
\hline & & person number & [times/day] & [times/person·day] \\
\hline A-1 & $12 / 1$ & 4 & 15 & 3.8 \\
A-2 & $12 / 2$ & 3 & 19 & 6.3 \\
A-3 & $12 / 3$ & 5 & 30 & 6.0 \\
B-1 & $12 / 1$ & 4 & 24 & 6.0 \\
B-2 & $12 / 2$ & 4 & 11 & 2.8 \\
B-3 & $12 / 3$ & 4 & 11 & 2.8 \\
C-1 & $12 / 1$ & 3 & 5 & 2.5 (Note) \\
C-2 & $12 / 2$ & 4 & 23 & 5.8 \\
C-3 & $12 / 3$ & 4 & 17 & 4.3 \\
\hline
\end{tabular}

Table 4. Results of toilet usage frequency and background correlation analysis (Quantification Type I).

\begin{tabular}{ccccc}
\hline Item name & Gender & \multicolumn{2}{c}{ Occupation } \\
\hline Range & 1.056 & 2 & 4.000 & 1 \\
Simple correlation coefficient & 0.233 & 2 & 0.384 & 1 \\
Partial correlation coefficient & 0.267 & 2 & 0.403 & 1 \\
\hline
\end{tabular}

Table 5. Toilet usage frequency according to occupation.

\begin{tabular}{cl}
\hline Pre-school & $2.7 \mathrm{times} /($ person·day) \\
Student & $4.5 \mathrm{times} /($ person·day) \\
Worker & $4.6 \mathrm{times} /($ person·day) \\
Unemployed (supplement value) & $7.3 \mathrm{times} /$ (person·day) \\
\hline
\end{tabular}

Although it is thought that a four-person household is typical, in Vietnam the number of people per household in 2002 was 4.44 and in 2012 it was 3.85 people (data from General Statistics Officer of Vietnam) and it is showing a slight declining trend. Also, in this study, as all the households were dual income, the average Vietnamese household model was a 4 person family with a dual-income couple, a student and an unemployed person. In this model, each person's household toilet usage frequency was $5.25 \mathrm{times} /($ person-day), and this was similar to a 2012 study [14] which showed a Hanoi model of 5.3 times/(person-day).

\section{Conclusions}

In order to establish a reference scenario of for Vietnamese household's future water usage, a controlled living experiment was conducted with Vietnamese high income earners from houses with consistent water pressure. A water usage profile was revealed of Vietnam's near-future households, based on continued urbanization, including their bathroom showering time, flow rate used, toilet use frequency. As a result, the showering time was on average $9.7 \mathrm{mi}$ - 
nutes/(person/day), flow rate of the existing shower was $12 \mathrm{~L} /$ minute, and the water-saving shower was $6.6 \mathrm{~L} /$ minute. The frequency of toilet usage was 5.25 times/(person/day), and there was no difference with the results of studies with average households (middle income earners). However, since the sample size was 9 households with 35 people, it is too small to say that the results represent Vietnam.

Future research will focus on Vietnamese homes and water used across a year, and further investigates the difference in water usage depending on income, in order to create a reference scenario.

\section{Acknowledgements}

This study was conducted as part of the Ministry of the Environment's "2014 Feasibility Study on Spreading low carbon, water-saving water supply and waste systems for a Low Carbon Asia”. We thank all the stakeholders involved.

\section{References}

[1] Yamazaki, H., Toyosada, K., Shimizu, Y. and Dejima, S. (2013) Potential for CO2 Reductions in Viet Nam by the Introduction of Water-Saving Showers. CIBW062 Symposium, 287-296.

[2] Akina, S., Subodh, S., Jana, G., Séverine, E., Sanjay, S., Rajendra, K., Christian, S., Peter, O., Jürg, U. and Guéladio, C. (2017) Water Quality, Sanitation, and Hygiene Conditions in Schools and Households in Dolakha and Ramechhap Districts, Nepal: Results from a Cross-Sectional Survey. Journal of Environmental Research and Public Health, 14, 1-21.

[3] Burul, A., Jilili, A., Gulnur, I. and Lamek, N. (2016) Consideration of Water Uses for Its Sustainable Management, the Case of Issyk-Kul Lake, Kyrgyzstan. Water, 8, $1-9$.

[4] Tafadzwanashe, M., Tendai, C. and Albert, M. (2016) Water-Food-Nutrition-Health Nexus: Linking Water to Improving Food, Nutrition and Health in Sub-Saharan Africa. Journal of Environmental Research and Public Health, 13, 1-19.

[5] Jim, W., Mawuli, D., Wardrop, N.A., Richard, J., Allan, H., Genevieve, A. and Richard, A. (2016) Effects of Sachet Water Consumption on Exposure to Microbe-Contaminated Drinking Water: Household Survey Evidence from Ghana. Journal of Environmental Research and Public Health, 13, 1-17.

[6] Makino, T., Noda, K., Keoduangchai, K., Hamada, H., Oki, K. and Oki, T. (2016) The Effects of Five Forms of Capital on Thought Processes Underlying Water Consumption Behavior in Suburban Vientiane. Sustainability, 8, 1-13.

https://doi.org/10.3390/su8060538

[7] Gert-Jan, W., Zita, S. and Renaud, F.G. (2014) Piped-Water Supplies in Rural Areas of the Mekong Delta, Vietnam: Water Quality and Household Perceptions. Water, 6, 2175-2194. https://doi.org/10.3390/w6082175

[8] Klassert, C., Sigel, K., Gawel, E. and Klauer, B. (2015) Modeling Residential Water Consumption in Amman: The Role of Intermittency, Storage, and Pricing for Piped and Tanker Water. Water, 7, 3643-3670. https://doi.org/10.3390/w7073643

[9] Cherunya, P.C., Janezic, C. and Leuchner, M. (2015) Sustainable Supply of Safe Drinking Water for Underserved Households in Kenya: Investigating the Viability of Decentralized Solutions. Water, 7, 5437-5457. https://doi.org/10.3390/w7105437 
[10] Kahler, D.M., Koermer, N.T., Reichl, A.R., Samie, A. and Smith, J.A. (2016) Performance and Acceptance of Novel Silver-Impregnated Ceramic Cubes for Drinking Water Treatment in Two Field Sites: Limpopo Province, South Africa and Dodoma Region, Tanzania. Water, 8, 1-21. https://doi.org/10.3390/w8030095

[11] Murakawa, S., Ikeda, D. and Doi, A. (2017) Estimation of Water Supply Loads for the Company Cafeteria, Hot-Water Service Rooms and Restrooms in an Office Building. Proceedings of the CIB-W062 International Symposium on Water Supply and Drainage for Buildings (The Netherlands), Haarlem, 23-25 August 2017, 195-206.

[12] Takata, H., Murakawa, S., Saito, C., Abe, M. and Toyosada, K. (2015) Development of the Calculating Method for the Loads of Cold and Hot Water Consumption in a Business Hotel (Part 1) Cold and Hot Water Demands through the Attributes of Guests and Plumbing Fixtures. Proceedings of the CIB-W62 International Symposium on Water Supply and Drainage for Buildings, 330-339.

[13] Kanako, T., Yasutoshi, S., Akihiko, I. and Kyosuke, S. (2013) Quantification of Environmental Impact Reduction Effect Resulting from Use of Water-Saving Toilet Bowls. J. Soc. Heat. Air-Cond. Sanit. Eng., 193, 1-8. (In Japanese)

[14] Study on the Modeling of Toilet Usage and Bathing Habits in Vietnam (2015). (In Japanese) http://www.shasej.org/ 